\title{
PERLINDUNGAN HUKUM BAGI SAKSI TINDAK PIDANA PEMBUNUHAN
}

\section{Fariaman Laila}

Sekolah Tinggi Ilmu Hukum Nias Selatan, Indonesia

Email: fariamanlaia35@gmail.com

\begin{abstract}
The purpose of this research is what is there to know and about the protection of the Law for Witnesses of Criminal Crimes. In this study using a type of normative legal research with the collection and inventory of legal data as well as, the analysis is qualitative. From which research the author, it can be about knowing the law around witnesses in criminal acts in the midst of physical protection, among others: supervision and escort, body security equipment, services and moreover, the cost of changing lives during the protection period, the cost of transportation changes and places during protection, protection in safe houses, realah and new identities, and legal protection, among others : information on the outcome of a case or court decision related to the report of who gave as much as half with internal regulations and laws and regulations, and laws and regulations. Goods and legal protection efforts in the case of regional and external criminal cases, criminal by means of legal means mainly, both criminal law materill, criminal lawmil or regional law where criminal criminal system for purposes and non-criminal or efforts outside the law more criminal minutes on the nature, antidote, outside let alone occur. The main point of this effort is the conducive factors that cause crime.
\end{abstract}

Keywords: legal protection; witnesses; criminal offences

\begin{abstract}
Abstrak
Tujuan penelitian ini adalah untuk mengetahui dan menganalisis tentang perlindungan hukum bagi saksi tindak pidana pembunuhan. Dalam penelitian ini menggunakan jenis penelitian hukum normatif dengan mengumpulkan dan menginventarivasi data hukum sekunder, kemudian analisis secara kualitatif. Dari hasil penelitian yang dilakukan penulis, maka diperoleh pengetahuan mengenai bentuk perlindungan hukum terhadap saksi dalam tindak pidana pembunuhan adalah perlindungan fisik, antara lain berupa: pengawasan dan pengawalan, penyediaan peralatan keamanan badan, pemberian layanan medis dan psikologis, penggantian biaya hidup selama masa perlindungan, penggantian biaya transportasi dan akomodasi selama dalam perlindungan, perlindungan di rumah aman, relokasi dan identitas baru dan perlindungan hukum antara lain berupa: menerima informasi perkembangan perkara atau putusan pengadilan terkait dengan laporan kesaksian yang diberikan sepanjang tidak bertentangan dengan peraturan internal dan peraturan perundangan-undangan, dan mendapat nasihat hukum. Hambatan dan upaya pemberian perlindungan hukum terhadap saksi dalam perkara tindak pidana pembunuhan yaitu hambatan internal dan eksternal, penal dengan menggunakan hukum pidana sebagai sarana utamanya, baik hukum pidana materill, hukum pidana
\end{abstract}

$\begin{array}{ll}\text { How to cite: } & \text { Laila, Fariaman (2021) Perlindungan Hukum Bagi Saksi Tindak Pidana Pembunuhan, Syntax Idea } \\ & \text { 3(4). http://dx.doi.org/10.36418/syntax-idea.1156 } \\ \text { E-ISSN: } & \text { 2684-883X } \\ \text { Published by: } & \text { Ridwan Institute }\end{array}$


formil maupun hukum pelaksanaan pidana yang dilaksanakan melalui sistem peradilan pidana untuk mencapai tujuan-tujuan tertentu dan non penal atau upaya diluar hukum pidana lebih menitik beratkan pada sifat preventif yaitu pencegahan, penangkalan, pengendalian sebelum kejahatan terjadi. Sasaran utama dari upaya ini adalah menangani faktor-faktor kondusif penyebab terjadinya kejahatan.

Kata kunci: perlindungan hukum; saksi; tindak pidana pembunuhan

\section{Pendahuluan}

Tindak pidana yang terungkap saat ini, dimana sebagian besar tidak lepas dari peran serta masyarakat dalam memberikan laporan tentang adanya pelanggaran hukum dan dalam upaya membantu tugas aparat penegak hukum mengungkap adanya suatu tindak pidana. Misalnya pembunuhan, tindak pidana ini tidak akan terungkap apabila tidak ada peran serta masyarakat dalam hal ini sebagai saksi. Untuk mengungkap tindak pidana yang menghilangkan nyawa orang lain ini merupakan kewajiban aparat penegak hukum, akan tetapi kontribusi masyarakat sangat penting terutama sebagai orang yang melihat, mendengar atau mengalami tindak pidana tersebut (Abdullah, 2016).

Perhatian terhadap saksi sampai saat ini masih jauh dari perhatian masyarakat dan aparat penegak hukum, menjadi persoalan utama, karena tidak adanya jaminan yang memadai atas perlindungan maupun mekanisme tertentu untuk bersaksi, bahkan sering kita jumpai banyaknya fakta dimana saksi yang akhirnya menjadi tersangka ataupun menjadi terpidana karena dianggap mencemarkan nama baik oleh pihak-pihak yang diduga telah melakukan tindak pidana. Dengan jaminan keamanan yang jauh dari apa yang diharapkan, membuat seseorang tidak bersedia menjadi saksi dan pada akhirnya menghambat proses peradilan pidana (Budoyo, 2008).

Muncul suatu dilema bagi saksi saat ini, di satu sisi harus memenuhi kewajibanya namun di sisi lain haknya tidak terpenuhi dan bahkan malah dirugikan oleh kepentingan pada pemeriksaan dalam setiap proses peradilan pidana. Kerugian yang diderita saksi adalah hak yang dilanggar oleh sebuah undang-undang. Keadaan yang demikian, tidak jarang saksi keberatan untuk memberikan keterangan atau kesaksian tentang adanya suatu tindak pidana dalam proses peradilan pidana.

Pentingnya jaminan keamanan dan perlindungan yang secara nyata dapat dirasakan seorang saksi, ditujukan agar orang tidak merasa takut untuk mengungkapkan suatu tindak pidana. Dengan adanya jaminan tersebut proses peradilan pidana dapat berjalan sesuai dengan fungsi dan tujuanya yaitu untuk mencari kebenaran materiil. Dengan tercapainya kebenaran materiil, maka akan tercapai pula tujuan akhir hukum acara pidana yaitu untuk mencapai suatu ketertiban, ketentraman, keadilan dan kesejahteraan dalam masyarakat (Hamzah, 2010).

Menjadi saksi merupakan kewajiban dari setiap warga Negara, dengan prinsip bahwa setiap saksi dalam memberikan keterangan harus mempunyai kebebasan, tanpa ada paksaan dari siapapun. Namun sekalipun saksi bebas memberikan keterangan, saksi juga dapat dituntut berdasarkan Pasal 242 Kitab Undang-Undang Hukum Pidana, apabila saksi memberikan keterangan yang tidak sesuai dengan yang sebenarnya 
(Samosir, 2013). Tetapi saksi juga harus dibebaskan dari perasaan takut, khawatir akan dampak dari keterangan yang diberikannya. Seseorang mungkin saja menolak untuk bersaksi, atau jika dipaksa berbohong karena ia tidak mau mempertaruhkan nyawanya atau nyawa keluarganya gara-gara keterangannya yang memberatkan terdakwa. Seseorang dapat menolak memberikan keterangan karena mengalami trauma hebat akibat peristiwa pidana, sehingga tidak memiliki kemampuan untuk menceritakan ulang peristiwa yang dialaminya itu. Tidak sedikit kasus yang tidak dapat dibawa ke muka pengadilan atau pun terhenti di tengah jalan karena persoalan yang satu ini. Kasus-kasus seperti korupsi atau kejahatan narkotika yang melibatkan sebuah sindikat, atau kasus-kasus kekerasan berbasis gender menjadi contoh kasus yang seringkali tidak dapat diproses karena tidak ada saksi yang mau dan berani memberikan keterangan yang sebenarnya. Maka yang terjadi kemudian adalah bukan saja gagalnya sebuah tuntutan untuk melakukan proses peradilan yang bersih, jujur dan berwibawa untuk memenuhi rasa keadilan, tetapi juga pelanggaran hak-hak asasi individual yang terkait dalam kasus tersebut.

Ketakutan saksi akan adanya balas dendam dari terdakwa cukup beralasan dan ia berhak diberi tahu apabila seseorang terpidana yang dihukum penjara akan dibebaskan, agar ia berhati-hati dalam kelangsungan kehidupannya. Berdasarkan dari berbagai kasus, terutama yang menyangkut kejahatan yang terorganisir, saksi dapat terancam walaupun terdakwa sudah dihukum. Dalam kasus kasus tertentu, saksi dapat diberi identitas baru, apabila keamanan saksi sudah sangat menghawatirkan, pemeberian tempat baru bagi saksi harus dipertimkbangkan agar saksi dapat meneruskan kehidupannya tanpa ketakutan, yang dimaksud dengan diberikannya kediaman baru adalah tempat tertentu bersifat sementara dan dianggap aman (Waluyo, 2011).

Melihat begitu pentingnya peran saksi, maka sudah seharusnya mereka mendapatkan perlindungan yang intensif. Perlindungan terhadap saksi dan korban sangat penting keberadaannya dalam proses peradilan pidana, hal ini sejalan dengan asas hukum yang tercantum di dalam Pasal 27 ayat (1) Undang-Undang Dasar 1945 "Segala warga negara bersamaan kedudukannya di dalam hukum dan pemerintahan dan wajib menjunjung hukum dan pemerintahan itu dengan tidak ada kecualinya". Pasal 7 tentang Deklarasi Universal Hak-Hak Asasi Manusia "Semua orang sama di depan hukum dan berhak atas perlindungan hukum yang sama tanpa diskriminasi. Semua berhak atas perlindungan yang sama terhadap setiap bentuk diskriminasi yang bertentangan dengan Deklarasi ini, dan terhadap segala hasutan yang mengarah pada diskriminasi semacam ini" (equality before the law). Guna memberikan jaminan perlindungan dan kepastian hukum untuk menjamin adanya proses peradilan pidana yang baik (due prosess of law) dan menciptakan peradilan yang fair dan bersih yang dapat menimbulkan rasa keadilan di masyarakat. Sehingga perlindungan terhadap saksi dan korban memiliki peranan penting dalam proses peradilan pidana, kemudian diharapkan dengan keterangan saksi dan korban yang diberikan secara bebas dari rasa takut dan ancaman dapat mengungkap suatu tindak pidana. 
Keberhasilan suatu proses peradilan pidana sangat tergantung pada alat bukti yang berhasil diungkap atau dimunculkan dalam persidangan, terutama saksi merupakan faktor penting dalam pengungkapan dan pembuktian fakta yang akan dijadikan acuan dalam menemukan bukti-bukti lain untuk menguatkan sebuah peneyelidikan, penyidikan dan pembuktian dipengadilan. Saksi dan korban sangat di harap dapat menjelaskan rangkain kejadian yang berkaitan dengan sebuah peristiwa yang menjadi objek pemeriksaan di muka persidangan. Saksi dan korban bersama alat bukti lain akan membantu hakim untuk menjatuhkan putusan yang adil dan objektif bedasarkan fakta-fakta hukum yang diungkapkan (Sunarso, 2012).

Seorang saksi ialah bagian dari sistem pradilan pidana, sehingga justru saksi tersebut akan menjadi faktor dalam mengurangi kejahatan, saksi berkewajiban untuk memberikan kesaksian demi memberantas kejahatan dalam masyarakat. Sebab setiap orang berkewajiban untuk ikut serta memberantas kejahatan dalam masyarakat (Lubis, 2017).

Para saksi dan korban seringkali tidak terlindungi keselamatannya dan terjadi intimidasi atau teror, akibatnya mereka enggan bersaksi di persidangan. Padahal saksi merupakan salah satu alat bukti di dalam pemeriksaan perkara pidana dimana keterangannya dapat membuktikan terjadi atau tidaknya suatu perbuatan pidana (Gultom, 2006). Salah satu contoh kasus yang berhubungan dengan perlindungan saksi antara lain kasus pembunuhan Salim Kancil dan penganiayaan Tosan, lima saksi dan satu korban yang masuk program perlindungan, perlindungannya berupa fisik kemudian pengawalan melekat dan bisa juga pendampingan pada proses hukum.

Penegakan hukum, khususnya hukum pidana merupakan salah satu tugas pokok dari negara. Penegakan hukum, pidana yang merupakan suatu proses penyelidikan, penyidikan, penangkapan dan penahanan sampai ke peradilan, hingga menjadi terpidana di Lembaga Pemasyarakatan (Lapas). Kesatuan proses itu disebut sistem peradilan pidana (Criminal Justice System) atau The Integrated Criminal Justice System (Kenedi, 2020). Selama ini, korban tindak pidana dapat dikatakan kurang mendapat perlindungan dari negara, baik fisik maupun secara ekonomi, termasuk juga keperluan-keperluan lainnya dalam memenuhi kewajiban sebagai saksi dalam suatu proses peradilan. Sementara pelaku tindak pidana selalu diawasi, mendapatkan perlakuan khusus demi proses hukum, bahkan kepada mereka diberikan makan dan minum secara teratur. Hal tersebut dimaksudkan agar perlindungan terhadap saksi dan korban dalam proses sistem peradilan pidana dapat terjamin, karena peranan saksi dan korban sangat penting dalam mengungkap suatu tindak pidana. Kepentingan utama adalah kepentingan masyarakat, artinya seseorang yang menjadi pelapor mau berkorban untuk kepentingan bersama, meskipun mengorbankan kepentingan pribadi (Yunus, 2012).

\section{Metode Penelitian}

1) Jenis Penelitian 
Penelitian ini menggunakan jenis penelitian hukum normative (legal research). Penelitian normatif sering pula disebut penelitian kepustakaan (liberary research), yaitu menganalisis dan mencari jawaban atas permasalahan yang diangkat berdasarkan substasi hukum/norma-norma hukum, sejarah hukum, asas-asas hukum, sistematika hukum, sinkronisasi hukum, dan perbandingan hukum guna memuat aturan tentang Perlindungan terhadap saksi (Undang-Undang Nomor 31, 2014) tentang Perlindungan Saksi dan Korban dan peraturan lain yang berhubungan dengan Perlindungan Hukum Bagi Saksi Tindak Pidana Pembunuhan.

2) Alat Pengumpulan Data

Dalam penelitian ini, data yang digunakan ialah data sekunder. Data sekunder adalah data yang diperoleh dari bahan-bahan pustaka (Soejono, 2015)Menurut soerjono Soekanto dan Sri Mahmuji, penelitian yang dilakukan dengan cara meneliti bahan pustaka atau data sekunder disebut penelitian hukum kepustakaan (Soejono, 2015). Cakupan data sekunder terdiri dari tiga jenis bahan hukum, yaitu:

1. Bahan hukum primer (primary law material)

2. Bahan hukum sekunder (secondary law material)

3. Bahan hukum tersier (tertiery law material)

Bahan hukum primer, yaitu bahan hukum yang bersifat autoritatif, artinya mempunyai otoritas, bahan-bahan hukum primer terdiri dari perundang undangan, catatan-catatan resmi atau risalah dalam pembuatan perundang udangan dan putusanputusan hakim. Bahan hukum sekunder, yaitu bahan hukum yang memberi penjelasan terhadap hukum primer yang berupa semua publikasi tentang hukum yang bukan merupakan dokumen-dokumen resmi, publikasi tentang hukum meliputi bukubuku teks, kamus-kamus hukum, jurnal-jurnal hukum, dan komentar-komentar atas putusan pengadilan. Bahan hukum tersier, yaitu bahan hukum yang memberi penjelasan terhadap bahan hukum primer dan bahan hukum sekunder (rancangan undang-undangan, kamus hukum, dan ensiklopedia).

3) Analisis Data

Analis data yang digunakan dalam penelitian ini adalah analisis data kulitatif, yaitu data yang telah dikumpulkan diinventariasi sesuai dengan bahan hukum primer dan bahan hukum sekunder, kemudian dianalisis deskriptis, logis dan sistematis dengan kerangka berpikir dilaksanakan secara deduktif dan induktif untuk membantu penelitian dalam melakukan penarikan kesimpulan.

\section{Hasil dan Pembahasan}

\section{a. Bentuk Perlindungan Hukum Bagi Saksi Tindak Pidana Pembunuhan}

1. Bentuk Ancaman dan Perlindungan

Bentuk ancaman yang dialami oleh Saksi yang mendapat perlindungan, antara lain:

a) Secara psikis merasa takut was-was atas laporan/keterangan yang telah dibuatnya; 
b) Mengalami intimidasi secara tidak langsung dari pihak lain atau terlapor untuk mencabut laporannya;

c) Secara langsung maupun tidak langsung mendapatkan teror/gangguan baik terhadap fisik, harta benda, maupun pekerjaan;

d) Akan dilaporkan balik oleh terlapor atau pihak lain;

e) Diikuti/diawasi/diintai oleh terlapor atau pihak lain yang terkait dengan laporannya;

f) Diancam secara tidak langsung yang dapat membahayakan jiwa;

g) Dipaksa baik secara langsung maupun tidak langsung untuk melakukan atau tidak melakukan sesuatu;

h) Diancam secara langsung dapat membahayakan jiwa dan harta bendanya;

i) Mendapatkan gangguan secara fisik yang dapat membahayakan jiwa dan harta benda.

2. Bentuk perlindungan yang dapat diberikan kepada Saksi yaitu:

1) Perlindungan Fisik, antara lain berupa:

a) Pengawasan dan pengawalan;

b) Penyediaan peralatan keamanan badan;

c) Pemberian layanan medis dan psikologis;

d) Penggantian biaya hidup selama masa perlindungan;

e) Penggantian biaya transportasi dan akomodasi selama dalam perlindungan;

f) Perlindungan di rumah aman;

g) Relokasidan identitas baru.

2) Perlindungan Hukum, antara lain berupa:

a) Menerima informasi perkembangan perkara atau putusan pengadilan terkait dengan laporanl kesaksian yang diberikan sepanjang tidak bertentangan dengan peraturan internal dan peraturan perundanganundangan;

b) Mendapat nasihat hukum.

Perlindungan hukum dapat diartikan sebagai setiap bentuk peraturan yang diatur dan didasarkan oleh peraturan perundangundangan berdasarkan kepastian hukum (Faisal, 2012).

3. Hambatan dan Upaya dalam mendapatkan Perlindungan Hukum Bagi Saksi

1) Hambatan dalam mendapatkan Perlindungan Hukum Bagi Saksi

Hambatan-hambatan yang selama ini masih mengganjal pelaksanaan perlindungan hukum terhadap saksi tindak pidana pembunuhan dapat dibagi 2 (dua) faktor adalah (Pitoy, 2016):

- Internal

Lembaga Perlindungan Saksi dan Korban (LPSK) sebagai lembaga yang paling potensial dan mempunyai kewenangan untuk memberikan perlindungan berdasarkan (Pasal 12 Undang-Undang Nomor 31 Tahun 2014 tentang Lembaga Perlindungan Saksi dan Korban, 2014) dinilai belum maksimal dan masih 
terdapat banyak kekurangan, baik itu dari LPSK sendiri maupun undang-undang yang mengaturnya. Pekerjaan LPSK tidak akan terlepas dari keberadaan beberapa lembaga penegak hukum yang ada. Dari segi politik hal ini membutuhkan seni dan cara penempatan yang baik agar bisa menempatkan diri pada posisi tersebut. LPSK secara jelas harus membangun posisi kelembagaannya yang berada diantara dua posisi kepentingan yakni kepentingan pertama yang dimandatkan oleh UU PSK sebagai lembaga yang bersifat mandiri, dan memiliki kepentingan kedua yakni untuk menjalankan program yang juga harus didukung oleh instansi terkait yang dalam praktiknya nanti akan menimbulkan keterkaitan kewenangan (Supriyadi Widodo Edyono dkk, 2008). Hambatan pelaksanaan perlindungan saksi dan korban dalam Undang-Unadang No. 13 Tahun 2006 tentang Perlindungan Saksi dan Korban antara lain (https://www. Hukum online. com/ klinik /detail /ulasan/lt4fb09c5c6a62d/ hambatan-hambatan- pelaksanaan-perlindungan-saksi-dan-korban/, 2021):

$>$ Belum adanya definisi mengenai pelapor, whistleblower dan justice collaborator (saksi pelaku yang bekerja sama);

$>$ Belum adanya jaminan perlindungan dan reward atau penghargaan terhadap whistleblower dan justice collaborator;

$>$ Belum adanya pengaturan mengenai perlindungan terhadap saksi ahli;

> Ketentuan kelembagaan Lembaga Perlindungan Saksi dan Korban ("LPSK") yang masih lemah mengenai kesekretariatan, organisasi, dan struktur organisasi LPSK;

$>$ Tidak adanya pengaturan lebih lanjut mengenai ketentuan pembentukan LPSK di daerah;

$>$ Keberadaan LPSK dan UU 13/2006 masih belum dipahami dan diketahui aparat penegak hukum di daerah;

> Jaminan hukum pemberian bantuan, restitusi, dan kompensasi yang saat ini belum cukup kuat karena hukum acaranya masih diatur dalam peraturan pemerintah bukan setingkat undang-undang.

Faktor-faktor internal penghambat perlindungan hukum terhadap saksi antara lain:

a. Definisi dan Status Saksi yang terbatas di dalam Undang-Undang Nomor 31 Tahun 2014 .

Undang-Undang Nomor 31 Tahun 2014 masih terdapat beberapa aturan atau pasal-pasal yang belum memadai untuk memberikan jaminan perlindungan kepada saksi. Diantaranya mengenai "definisi saksi" yang terbatas. Dalam konteks "definisi saksi" yang terbatas tersebut, UU No. 31 Tahun 2014 juga (tidak ada ditemukan/diatur) melupakan orang-orang yang memberikan bantuan kepada aparat penegak hukum untuk keterangan dan membantu proses pemeriksaan pidana yang berstatus ahli (orang yang memiliki keahlian khusus).

b. Inkonsistensi pasal-pasal di dalam Undang-Undang Nomor 31 Tahun 2014 
Di dalam Undang-Undang Nomor 31 Tahun 2014 jangka waktu yang diberikan tidak konsisten. Yang dimaksudkan dalam Perlindungan dalam UU ini adalah segala upaya pemenuhan hak dan pemberian bantuan untuk memberikan rasa aman kepada saksi dan/atau korban yang wajib dilaksanakan oleh LPSK atau lembaga lainnya sesuai dengan ketentuan undang-undang ini. Namun undang-undang ini memberikan perlindungan pada saksi dan korban terbatas hanya dalam semua tahap proses peradilan pidana dalam lingkungan peradilan. Pasal ini akan membatasi jangka waktu perlindungan karena pengertian tahap proses peradilan pidana ini hanya mencakup tahap penyelidikan sampai dengan pemberian putusan yang final, padahal dalam kondisi tertentu dimana kejahatan yang ada sifatnya serius proteksi perlindungan saksi harus diberikan pula pada tahapan setelah proses peradilan pidana. Lagi pula Pasal-pasal tersebut tidak konsisten bila dikaitkan dengan Pasal 5 huruf f, huruf h, huruf i yang memberikan kepada saksi hak untuk untuk mendapat informasi mengenai perkembangan kasus, hak mengetahui dalam hal terpidana di bebaskan dan hak identitas baru.

Hak-hak ini diberbagai negara dalam prakteknya justru diberikan setelah kasus selesai di proses dalam peradilan pidana, bahkan untuk perlindungan dengan cara penggantian identitas maupun relokasi yang permanen bagi saksi, tahapan pemberiannya seharusnya menjangkau waktu yang sangat lama atau diberikan secara permanen (seumur hidup) (Widodo, 2006).

c. Lembaga Perlindungan Saksi dan korban (LPSK) yang belum memiliki perwakilan di daerah dan kurangnya sosialisasi.

Lembaga Perlindungan Saksi dan Korban (LPSK) masih memiliki beberapa kekurangan sehingga belum maksimal dalam menjalankan tugasnya. Diantaranya yaitu lembaga tersebut yang hanya berkedudukan di Ibu Kota Negara Republik Indonesia. LPSK tidak memiliki perwakilan di daerah-daerah, hal tersebut menyulitkan LPSK dalam menjangkau daerahdaerah lain mengingat wilayah Negara Indonesia yang sangat luas.

d. Belum Adanya Mekanisme Perlindungan Sementara bagi Saksi dalam Kondisi Darurat. Berkaitan dengan tata cara pemberian perlindungan saksi, Undang-Undang ini sengaja tidak memasukkan mekanisme perlindungan sementara terhadap saksi dalam kondisi mendesak seperti yang telah dipraktekkan lembaga perlindungan saksi di berbagai Negara argumentasinya mungkin karena jangka waktu putusan pemberian perlindungan oleh LPSK cukup pendek yakni 7 hari, maka tidak diperlukan perlindungan yang mendesak. Mekanisme perlindungan mendesak ini sangatlah penting, karena kadangkala dalam sebuah kasus, baik intimidasi dan ancaman kadangkala diberikan secara cepat sesaat seorang saksi akan memberikan informasi ke aparat hukum. Oleh karena itu diperlukan mekanisme yang cepat (diluar caracara biasa) untuk melindungi saksi - saksi dalam kondisi seperti ini (Widodo, 2006). 
e. Pembatasan Tugas dan Wewenang Lembaga Perlindungan Saksi dan Korban

Undang-Undang PSK secara tegas menyatakan bahwa LPSK adalah lembaga yang mandiri. Kemandirian LPSK yang dimaksud oleh undangundang ini, adalah sebuah lembaga yang independen tanpa campur tangan dari pihak manapun. Idealnya sebuah lembaga yang mandiri inilah maka UU PSK tidak meletakkan struktur LPSK berada di bawah institusi manapun, baik itu instansi pemerintah (eksekutif) misalnya kepolisian, kejaksaan, departemen pemerintahan, maupun lembaga independen lainnya seperti Komisi Nasional Hak Asasi Manusia, Komisi Pemberantasan Korupsi, dan komisi-komisi negara lainnya. UU LPSK menetapkan model lembaga ini hampir sarna dengan berbagai lembaga yang telah ada seperti : Komnas HAM, KPK, PPATK dan lain sebagainya. Hal ini menunjukkan pula bahwa lembaga tersebut merupakan sebuah state auxiliaries.

Undang-Undang Nomor 31 Tahun 2014 dalam ketentuan umumnya telah menyatakan bahwa Lembaga Perlindungan Saksi dan Korban (LPSK) adalah lembaga yang bertugas dan berwenang untuk memberikan perlindungan dan hak-hak lain kepada Saksi dan/atau Korban sebagaimana diatur dalam Undang-Undang. Namun UU LPSK tidak merinci tugas dan kewenangan dari ketidaksepahaman Lembaga Perlindungan Saksi Dan Korban Dengan PihakPihak Terkait.

Seiring berjalannya waktu LPSK dalam melaksanakan tugas dan fungsinya tidak selalu berjalan sesuai dengan apa yang diinginkan. Banyak hal yang terjadi sehingga menimbulkan masalah di dalam segala kegiatan LPSK dalam melindungi saksi terutama saksi dalam tindak pidana korupsi. Salah satu masalah yang terjadi adalah timbulnya ketidaksepahaman antara LPSK dengan pihak-pihak terkait yang berwenang. Hal ini tentu akan menghambat tugas paling utama dari LPSK yaitu melindungi saksi dan atau korban (Pasal 12 Undang-Undang Nomor 31 Tahun 2014 tentang Lembaga Perlindungan Saksi dan Korban, 2014).

f. Permasalahan Internal Kelembagaan LPSK

Undang-Undang LPSK menyatakan LPSK terdiri atas, Pimpinan dan Anggota. Pimpinan LPSK terdiri atas Ketua dan Wakil Ketua yang merangkap anggota yang dipilih dari dan oleh anggota LPSK Mengenai tata cara pemilihan Pimpinan LPSK akan diatur dengan peraturan internal LPSK nantinya. Sedangkan masa jabatan Ketua dan Wakil Ketua LPSK ditetapkan oleh UU selama 5 (lima) tahun dan sesudahnya dapat dipilih kembali dalam jabatan yang sarna, hanya untuk 1 (satu) kali masa jabatan berikutnya. Undang-Undang, anggota dari LPSK terdiri atas 7 (tujuh) orang yang berasal dari unsur profesional yang mempunyai pengalaman di bidang pemajuan, pemenuhan, perlindungan, penegakan hukum dan hak asasi manusia. UU LPSK juga telah menetapkan siapa saja (representasi) yang berhak menjadi anggota dari lembaga ini yakni representasi dari : kepolisian, kejaksaan. 
Departemen Hukum dan Hak Asasi Manusia, Komnas HAM, advokat, akademisi atau lembaga swadaya masyarakat.

Menurut Marthin Simangunsong, meskipun ada Undang-Undang Perlindungan Saksi dan Korban belum dapat menampung keinginan dan menjalankan Undang-Undang itu secara menyeluruh karena sampai saat ini Lembaga Perlindungan Saksi dan Korban hanya terdapat di Jakarta sehingga di daerah-daerah lain yang membutuhkan perlindungan kurang mendapatkan perlindungan hukum. Apabila terhadap pembunuhan berencana, saksi takut mendapatkan ancaman dari si pelaku ataupun pihak terdekat dari si pelaku dalam memberikan keterangan atas kesaksiannya. Bisa juga polisi menyudutkan saksi sehingga saksi takut memberikan keterangannya di depan persidangan. Masalah yang biasanya timbul terjadi yaitu adanya sumber anggaran dan sumber daya manusia yang minim sehingga perlindungan hukum yang diatur dalam Undang-Undang perlindungan saksi dan korban kurang efektif dalam penerapannya.

- Eksternal

Pengertian saksi yang telah dijelaskan dalam ketentuan Pasal 1 ayat (1) Undang-Undang Nomor 31 Tahun 2014 tentang Perlindungan Saksi dan Korban, yang dimaksud dengan saksi adalah "orang yang dapat memberikan keterangan guna kepentingan penyelidikan, penyidikan, penuntutan, dan pemeriksaan di sidang pengadilan tentang suatu perkara pidana yang ia dengar sendiri, ia lihat sendiri, dan/atau ia alami sendiri.

Pasal 5 ayat (2) menyebutkan bahwa : "Hak sebagaimana dimaksud pada ayat (1) diberikan kepada Saksi dan/atau Korban tindak pidana dalam kasuskasus tertentu sesuai dengan keputusan LPSK." Pasal 5 ayat (2) hanya memberikan hak sebagaimana yang dimaksud pada ayat (1) kepada saksi dan/atau korban tindak pidana dalam kasus-kasus tertentu sesuai dengan keputusan LPSK. Di sini yang dimaksud dengan kasus-kasus tertentu sebagaimana penjelasan pasal demi pasal antara lain, tindak pidana korupsi, tindak pidana narkotika/psikotropika, tindak pidana terorisme, dan tindak pidana lain yang mengakibatkan posisi saksi dan/atau korban dihadapkan pada situasi yang sangat membahayakan jiwanya.

Menurut Marthin Simangunsong, Hambatan eksternal dalam perlindungan saksi disebabkan oleh beberapa faktor sebagai berikut:

1. Masih rendahnya tingkat pendidikan;

2. Faktor ekonomi;

3. Rasa takut bertemu dengan penyidik atau Polisi;

4. Tidak mengetahui adanya undang-undang perlindungan saksi;

5. Adanya ancaman, baik fisik maupun psikis dari pihak tertentu.

4. Upaya dalam mendapatkan Perlindungan Hukum Bagi Saksi 
Peneliti Institute for Criminal Justice (ICJR), Sustira Dirga menambahkan, terkait proses seleksi pimpinan LPSK yang akan dijalankan, pihaknya mendorong agar DPR mencari figur-figur yang berintegritas, berkualitas dan memiliki motivasi pengabdian masyarakat yang kuat. Guna menjalankan tugas dan wewenang LPSK. DPR harus menggali lebih dalam terkait rencana strategis beserta visi misi para calon anggota atau pimpinan LPSK agar arah LPSK ke depan lebih optimal lagi, dalam rangka menjalankan mandat untuk melindungi saksi dan korban. Keterbukaan informasi publik sebagaimana amanat UndangUndang Keterbukaan Informasi Publik juga perlu menjadi perhatian LPSK ke depannya. Serta postur anggaran yang lebih optimal lagi dalam rangka memberikan perlindungan saksi dan pemenuhan hak korban sesuai dengan mandat utama LPSK. Karena keterbatasan anggaran perlindungan, pada beberapa pelaksanaan perlindungan saksi atau korban ternyata LPSK menyimpangi SOP perlindungannya. Misalnya kepada terlindung hanya diberikan 1 orang pengamanan, dan 1 staff yang merangkap administrasi dan manajer kasus. Padahal seharusnya bagi seorang terlindung, minimal harus ada 2 orang pengamanan, 1 orang manajer kasus, dan 1 staff administrasi Kebijakan Hukum Pidana

Kebijakan penanggulangan kejahatan atau criminal policy merupakan usaha yang rasional dari masyarakat sebagai reaksi mereka terehadap kejahatan. Sebagai bagian dari kebijakan penegakan hukum (law enforcement policy) kebijakan penggulangan kejahatan harus mampu menempatkan setiap komponen sistem hukum dalam arah yang kondusif dan aplikatif untuk menanggulangi kejahatan, termasuk peningkatan budaya hukum masyarakat sehingga mau memberikan partisipasi yang aktif dalam penanggulangan .kejahatan. Oleh karena itu kebijakan penanggulangan kejahatan harus dilakukan melalui perencanaan yang rasional dan menyeluruh sebagai respon terhadap kejahatan (Chazawi, 2000).

Kebijakan penal atau sering disebut politik hukum pidana merupakan upaya menentukan kearah mana pemberlakuan hukum pidana Indonesia masa yang akan datang dengan melihat penegakannya saat ini. Hal ini berkaitan dengan konseptualitas hukum pidana yang paling baik untuk diterapkan (Mahmud Mulyadi, 2008). Usaha dan kebijakan untuk membuat peraturan hukum pidana yang baik pada hakikatnya tidak dapat dilepaskan dari tujuan penanggulangan kejahatan, juga merupakan bagian dari usaha penegakan hukum, khususnya penegakan hukum pidana. Usaha penanggulangan kejahatan lewat pembuatan undang-undang hukum pidana pada hakikatnya juga merupakan bagian integral dari usaha perlindungan masyarakat (social defence) dan usaha mencapai kesejahteraan masyarakat (sosial walfare).

Menurut A. Mulder, politik hukum pidana merupakan garis kebijakan untuk menentukan (Arief, 2011). 
a. Seberapa jauh ketentuan - ketentuan pidana yang berlaku perlu diubah atau diperbarui.

b. Apa yang dapat diperbuat untuk mencegah terjadinya tindak pidana.

c. Cara bagaimana penyidikan, penuntutan, peradilan dan pelaksanaan pidana harus dilaksanakan.

Kebijakan kriminal tidak dapat dilepaskan sama sekali dari masalah nilai, terlebih bagi bangsa Indonesia yang berdasarkan Pancasila dan garis kebijakan pembangunan nasionalnya bertujuan untuk membentuk manusia Indonesia seutuhnya. Penggunaan sanksi pidana, tidak hanya berarti bahwa pidana yang dikenakan pada sipelanggar harus sesuai dengan nilai-nilai kemanusiaan yang beradab, tetapi harus dapat membangkitkan kesadaran si pelanggar akan nilai-nilai kemanusiaan dan nilai pergaulan hidup masyarakat.

Upaya penanggulangan kejahatan lewat jalur penal atau hukum pidana lebih menitik beratkan pada sifat refresif yaitu berupa pemberantasan atau penumpasan sesudah kejahatan terjadi. Upaya ini dilakukan apabila preventif atau upaya pencegahan belum mampu untuk mencegah terjadinya kejahatan. Upaya penal yang dapat dilakukan untuk menanggulangi kekerasan baik dilaporkan masyarakat maupun temuan kepolisian akan dilakukan tindakan tegas atau penegakan hukum secara tuntas dengan tujuan agar para pelaku menjadi sadar dan jera untuk berbuat kembali. Menjatuhkan hukuman yang maksimal yang sesuai dengan ketentuan KUHP kepada pelaku pembunuhan. Kebijakan hukum yang dapat dijatuhkan bagi para pelaku pembunuhan mengacu pada KUHP yang disesuaikan dengan pasal-pasal pembunuhan terhadap jiwa orang berdasarkan perbuatan pelaku dengan korban dalam pembuktian kasus disesuaikan dengan pembuktian kasus sesuai dengan pembuktian KUHP. Tujuan dari politik kriminal adalah perlindungan masyarakat untuk mencapai kesejahteraan masyarakat, dalam upaya penanggulangan kejahatan perlu ditempuh dengan pendekatan kebijakan dalam arti, yaitu:

1. Ada keterpaduan (intergralitas) antara politik kriminal dan politik sosial;

2. Ada keterpaduan (intergralitas) antara upaya penanggulangan kejahatan dengan "penal" dan "non penal".

Kebijakan hukum pidana pada hakikatnya merupakan usaha untuk mewujudkan peraturan perundang-undangan pidana agar sesuai dengan keadaan pada waktu tertentu (ius constitutum) dan masa mendatang (ius constituendum). Kebijakan hukum pidana identik dengan penal reform dalam arti sempit, karena sebagai suatu system hukum pidana terdiri dari budaya (cultural), stuktur (structur), dan substansi (substansive) hukum. Undangundang merupakan bagian dari substansi hukum, pembaharuan hukum pidana, disamping memperbaharui perundang-undangan juga mencakup pembaharuan ide dasar dan ilmu hukum pidana. 


\section{Non Penal}

Upaya non penal atau upaya diluar hukum pidana lebih menitik beratkan pada sifat preventif yaitu pencegahan, penangkalan, pengendalian sebelum kejahatan terjadi. Sasaran utama dari upaya ini adalah menangani faktorfaktor kondusif penyebab terjadinya kejahatan. Faktor-faktor kodusif antara lain berpusat pada masalah-masalah atau kondisi-kondisi sosial yang secara langsung atau tidak langsung dapat menimbulkan atau menumbuhsuburkan kejahatan. Dengan demikian, dilihat dari sudut politik criminal secara makro dan global maka non penal menduduki posisi kunci dan strategis dari keseluruhan upaya politik criminal. Upaya non penal yang paling strategis adalah upaya untuk manjadikan masyarakat sebagai lingkungan sosial dan lingkungan hidup yang sehat secara materil dan imateril dari faktor-faktor krominogen (Barda Nawawi Arif, 2002).

Kebijakan penanggulangan kejahatan lewat jalur "non penal" lebih bersifat tindakan pencegahan sebelum terjadinya kejahatan. Sasaran utamanya adalah menangani faktor-faktor kondusif penyebab terjadinya kejahatan yang berpusat pada masalah-masalah atau kondisi-kondisi sosial yang secara langsung atau tidak langsung dapat menimbulkan atau menumbuh suburkan kejahatan (Martiman Prodjohamidjojo, 1986).

Pertanggungawaban terhadap segala tugas yang dijalankan sebagai alat Negara, maka yang bertanggungjawab atas tugas kenegaraan tesebut adalah Negara. Dan terhadap oknum penegak hukum, yang dipandang mungkin perlu dikoreksi atau dianggap tidak cakap menjalankan tugasnya, maka hal tersebut diserahkan sepenuhnya kepada masing-masing instansi.

\section{Kesimpulan}

Berdasarkan hasil penelitian sebagaimana yang telah dibahas dari berbagai bagian dari atas maka dapat ditarik kesimpulan dan saran sebagai berikut: Bentuk perlindungan hukum terhadap saksi dalam tindak pidana pembunuhan adalah Perlindungan Fisik, antara lain berupa: Pengawasan dan pengawalan, Penyediaan peralatan keamanan badan, Pemberian layanan medis dan psikologis, Penggantian biaya hidup selama masa perlindungan, Penggantian biaya transportasi dan akomodasi selama dalam perlindungan, Perlindungan di rumah aman, Relokasi dan identitas baru, dan Perlindungan Hukum, antara lain berupa: Menerima informasi perkembangan perkara atau putusan pengadilan terkait dengan laporan kesaksian yang diberikan sepanjang tidak bertentangan dengan peraturan internal dan peraturan perundangan-undangan, dan Mendapat nasihat hukum. Hambatan dan upaya perlindungan hukum terhadap saksi tindak pidana pembunuhan adalah banyak masyarakat yang enggan menjadi saksi karena banyak kasus yang terjadi sesudah menjadi saksi justru mereka mendapatkan ancaman, kehilangan pekerjaannya, dianiaya dan sampai nyawa mereka pun terancam, pengawasan dari penegak hukum terhadap kejadian tersebut yang mengakibatkan pelaku bisa berbuat sewenang-wenang kepada saksi, karena keterangan dari saksi sangat 
berpengaruh terhadap hukuman yang akan di berikan kepada pelaku. Kurangnya perhatian masyarakat terhadap pengawasan atau perhatian kepada lingkungan sekitar, minimnya ilmu pengetahuan tentang hukum yang di miliki oleh masyarakat membuat masyarakat kurang mengetahui apakah haknya sudah di jalankan atau belum. 


\section{BIBLIOGRAFI}

Abdullah, Said. (2016). Penegakan Hukum terhadap Pelaku Tindak Pidana Perburuan dan Perdagangan Satwa Liar yang Dilindungi di Wilayah Balai Konservasi Sumber Daya Alam Jambi (Analisis Kasus No. 644/Pid. Sus/Pn. Jmb). Legalitas: Jurnal Hukum, 8(2), 48-72.Google Scholar

Arief, Barda Nawawi. (2011). Pembaharuan hukum pidana dalam perspektif kajian perbandingan. Citra Aditya Bakti.Google Scholar

Barda Nawawi Arif. (2002). Bunga Rampai Kebijakan Hukum Pidana. Bandung: Citra Aditiya Bakti.Google Scholar

Budoyo, Sapto. (2008). Perlindungan hukum bagi saksi dalam Proses peradilan pidana. Program Pasca Sarjana Universitas Diponegoro.Google Scholar

Chazawi, Adami. (2000). Kejahatan Tubuh dan Nyawa. PT. Raja Grafindo Persada. Jakarta.Google Scholar

Faisal, S. (2012). Menerobos Positivisme Hukum, Kritik terhadap Peradilan Asrori. Gramata Publishing, Bekasi.Google Scholar

Gultom, Binsar. (2006). Pandangan Seorang Hakim Penegakan Hukum Di Indonesia. Pustaka Bangsa Press, Medan.Google Scholar

Hamzah, Andi Jur. (2010). Hukum acara pidana Indonesia.Google Scholar

https://www. Hukum online. com/ klinik /detail /ulasan/lt4fb09c5c6a62d/ hambatanhambatan- pelaksanaan-perlindungan-saksi-dan-korban/. (2021).

Kenedi, John. (2020). Hasil cek Plagiat Karya Ilmiah: Perlindungan Saksi Dan Korban (Studi Perlindungan Hukum Korban Kejahatan dalam Sistem Peradilan di Indonesia).Google Scholar

Lubis, Riska Oktavia. (2017). Perlindungan Saksi dan korban menurut hukum islam dan undang-undang nomor 31 tahun 2014 tentang perlindungan saksi dan korban. UIN Raden Intan Lampung. Google Scholar

Mahmud Mulyadi. (2008). Criminal Policy. Medan: Pustaka Bangsa Perss.Google Scholar

Martiman Prodjohamidjojo. (1986). Ganti Rugi dan Rehabilitasi. Jakarta: Ghalia Indonesia.

Pasal 12 Undang-Undang Nomor 31 Tahun 2014 tentang Lembaga Perlindungan Saksi dan Korban. (2014).

Pitoy, Frances Esther Vaticanaq. (2016). Perlindungan Hukum terhadap Saksi dalam 
Proses Peradilan Pidana Berdasarkan Undang-undang Nomor 13 Tahun 2006 Tentang Perlindungan Saksi dan Korban. Lex Crimen, 5(1).Google Scholar

Samosir, Djisman. (2013). Segenggam tentang hukum acara pidana. Segenggam tentang hukum acara pidana.Google Scholar

Soejono, Sri Mahmuji. (2015). Penelitian Hukum Normatof Suatu Tinjauan Singkat, Cetakan 17, Edisi 1. Jakarta: Rajawali Pers.Google Scholar

Sunarso, Siswantoro. (2012). Viktimologi dalam sistem peradilan pidana. Sinar Grafika.Google Scholar

Supriyadi Widodo Edyono dkk. (2008). Pokok-Pokok Pikiran Penyusunan Cetak Biru Lembaga Perlindungan Saksi dan Korban, ICW. Jakarta.

Undang-Undang Nomor 31. (2014). Perlindungan Saksi dan Korban.

Waluyo, Bambang. (2011). Viktimologi perlindungan korban \& saksi. Sinar Grafika.

Widodo, Supriyadi. (2006). Perlindungan Saksi, Belum Progresif, Catatan Kritis Terhadap Hasil Pembahasan Perlindungan Saksi dan Korban. ELSAM, Jakarta.Google Scholar

Yunus, Nur Rohim. (2012). Restorasi Budaya Hukum Masyarakat Indonesia. Bogor: Jurisprudence Press.Google Scholar

\section{Copyright holder :}

Fariaman Laila (2021)

First publication right :

Journal Syntax Idea

This article is licensed under:

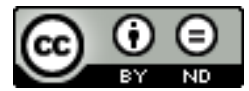

